Hasan: Keterampilan Mengajar Bahasa Arab Materi Istima Menggunakan Media Lagu

\title{
KETERAMPILAN MENGAJAR BAHASA ARAB MATERI ISTIMA MENGGUNAKAN MEDIA LAGU
}

\author{
Hasan \\ Dosen Prodi PBA Sekolah Tinggi Ilmu Alquran/STIQ Amuntai \\ Email: hasanbanjary@gmail.com
}

\begin{abstract}
Abstrak
Istima' atau menyimak adalah suatu keterampilan yang hingga sekarang agak diabaikan dan belum mendapat tempat yang sewajarnya dalam pengajaran bahasa Arab. Masih kurang sekali materi berupa buku teks dan sarana lain, seperti rekaman yang digunakan untuk menunjang tugas guru dalam pengajaran menyimak untuk digunakan di Indonesia. Ketika keterbatasan media yang ada, guru dituntut untuk memberikan pembelajaran yang sebaiknya. Untuk mengatasi permasalahan tersebut guru harus bisa berinovasi dalam mengajar. Salah satu bentuk inovasi adalah dengan menggunakan media lagu dalam mengajarkan materi istma'. Di tangan seorang guru yang kreatif dan inovatif media lagu fungsi awalnya untuk menghibur juga dapat digunakan untuk mengajar, sehingga anak didik merasa senang dalam belajar bahasa Arab.
\end{abstract}

Kata kunci: Istima', media, lagu

\section{A. Pendahuluan}

Menyimak adalah suatu proses kegiatan mendengarkan lambang-lambang lisan dengan penuh perhatian, pemahaman, apresiasi serta intrepretasi untuk memperoleh informasi, menangkap isi serta memahami makna komunikasi yang tidak disampaikan oleh si pembicara melalui ajaran atau bahasa lisan ${ }^{1}$.

Dalam bahasa Arab mendengar dan menyimak disebut istima'. Mendengar dan menyimak dalam bahasa Arab sulit dilakukan karena bahasa arab itu merupakan bahasa asing di Indonesia, sehingga tingkat menyimak ini adalah kegiatan yang memerlukan ketekunan dalam mempelajarinya. Menyimak dalam bahasa Arab akan dapat dicapai melalui suatu latihan-latihan, sehingga mampu membedakan bahasa

${ }^{1}$ Henry Guntur Tarigan, Menyimak sebagai suatu keterampilan berbahasa, (Bandung Angkasa ,1985), hal.19.

Jurnal Ilmiah Al QALAM, Vol. 10, No. 19, Januari-Juni 2017 
Hasan: Keterampilan Mengajar Bahasa Arab Materi Istima Menggunakan Media Lagu

lisan dan memahami isinya. Hal ini beralasan bahwa bahasa Arab dalam hal menyimak harus memerlukan latihan secara intensif dan kontinyu karena mayoritas dari kita agak sulit dalam memahami dan mengerti bahasa Arab.

Keterampilan menyimak (maharah al-istima'/listening skill) adalah kemampuan seseorang dalam mencerna atau memahami kata atau kalimat yang diujarkan oleh mitra bicara atau media tertentu. Kemampuan ini sebenarnya dapat dicapai dengan latihan yang terus menerus untuk mendengarkan perbedaan-perbedaan bunyi unsur-unsur kata (fonem) dengan unsur-unsur lainnya menurut makhraj huruf yang betul baik langsung dari penutur aslinya (al-nathiq al-ashli) maupun melalui rekaman. ${ }^{2}$

Menyimak adalah suatu keterampilan yang hingga sekarang agak diabaikan dan belum mendapat tempat yang sewajarnya dalam pengajaran bahasa. Masih kurang sekali materi berupa buku teks dan sarana lain, seperti rekaman yang digunakan untuk menunjang tugas guru dalam pengajaran menyimak untuk digunakan di Indonesia.

Sebagai salah satu keterampilan reseptif, keterampilan menyimak menjadi unsur yang harus lebih dahulu dikuasai oleh pelajar. Memang secara alamiah pertamakali manusia memahami bahasa orang lain lewat pendengaran, maka dalam pandangan konsep tersebut, keterampilan berbahasa Asing yang harus didahulukan adalah menyimak. Sedangkan membaca adalah kemampuan memahami yang berkembang pada tahap selanjutnya.

Istima' (menyimak) adalah proses menerima sekumpulan fitur bunyi yang terkandung dalam kosakata, atau kalimat yang memiliki

${ }^{2}$ Acep Hermawan, Metodologi Pembelajaran Bahasa Arab, (Bandung: PT.Remaja Rosdakarya, 2011), hal.130.

Jurnal Ilmiah Al QALAM, Vol. 10, No. 19, Januari-Juni 2017 
Hasan: Keterampilan Mengajar Bahasa Arab Materi Istima Menggunakan Media Lagu

makna terkait dengan kata sebelumnya, dalam sebuah topik tertentu. Istima' juga dapat diartikan yaitu memahami berbagai nuansa makna ragam teks lisan dengan ragam variasi tujuan komunikasi dan konteks, Abdul Majid Sayyid Ahmad Mansur mendefinisikan istima': Yaitu proses mendengarkan dengan serius kode-kode bahasa yang diucapkan kemudian ditafsirkan.

Bahasa Arab merupakan bahasa manusia atau produk budaya Arab. Ia bukan bahasa Tuhan atau malaikat, meskipun kalam Allah (Alquran) diwahyukan kepada nabi Muhammad Saw dalam bahasa Arab. Maka sebagai produk dan sistem budaya, bahasa Arab mempunyai dimensi akademik, humanistik, dan pragmatik. Ia tunduk pada sistem linguistik yang telah menjadi kesepakatan penutur bahasa ini, baik sistem fonologi (ashwat), morfologi (sharf), sintaksis (nahwu) dan semantik (dilalah). Oleh karena itu, studi dan kajian terhadap bahasa Arab sangat menarik baik dari segi linguistik, maupun kajian terapan seperti psikolinguistik (ilmu psikologi dan linguistik) dan sosiolinguistik (ilmu sosial dan linguistik) serta aspek pembelajaran bahasa Arab itu sendiri. ${ }^{3}$

Ada anggapan yang menyatakan bahasa Arab merupakan bahasa yang sulit dipelajari baik itu dari segi kalimat (kata dalam bahasa Indonesia) maupun dari segi yang lainnya. Stigma negatif tentang sulitnya belajar bahasa Arab sebenarnya merupakan propaganda Barat/kolonialis agar umat Islam sedikit demi sedikit menjauhi agamanya, karena bahasa Arab adalah bahasa Al Quran sehingga bila umat Islam jauh dengan Al Quran maka akan jauh pula

${ }^{3}$ Ahmad Muradi, Pembelajaran Menulis Bahasa Arab Dalam Perspektif Komunikatif, (Jakarta: Prenada Media Group, 2015) hal. 2.

Jurnal Ilmiah Al QALAM, Vol. 10, No. 19, Januari-Juni 2017 
Hasan: Keterampilan Mengajar Bahasa Arab Materi Istima Menggunakan Media Lagu

dengan agamanya. ${ }^{4}$ Ketika anggapan tersebut sudah masuk dalam otak bawah sadar peserta didik, bagaimana pun mudahnya masih saja dikatakan sulit. Kesulitan tersebut biasanya diawali dengan sedikitnya atau bahkan tidak ada sama sekali pemerolehan bahasa Arab peserta didik disamping permasalahan-permasalahan yang lainnya. Pernyataan seperti di atas dapat kita pastikan dengan menanyakan hal tersebut kepada peserta didik kita semua, mayoritas dari mereka akan menjawab seperti jawaban di atas.

Ketika keadaan seperti itu, selayaknya sebagai pengajar (guru, dosen maupun ustadz bahasa Arab) mencari solusi/jalan keluar dari permasalahan tersebut sehingga stigma negatif tentang bahasa Arab semakin pudar dan menghilang sehingga peserta didik akan bersemangat dalam belajar bahasa Arab.

Kemampuan dasar manusia untuk berbahasa merupakan kemampuan yang sejalan dengan potensi hidup manusia sebagai sarana ujaran sekaligus alat hidup untuk saling mengenal dan berinteraksi, meskipun demikian, kemampuan dan tingkat perkembangan ujaran sebagai penampilannya erat hubungnnya dengan tingkat kecerdasan dan perkembangan kreatifitas seseorang juga erat hubungannya dengan pertimbangan individu yang dilandasi nilai-nilai tertentu. Oleh karena itu timbul berbagai macam bahasa yang dipengaruhi oleh adanya dialek atau latar belakang suatu daerah tertentu, salah satunya adalah bahasa Arab dipakai sebagai bahasa sehari-hari oleh bangsa arab dan negaranegara sekitarnya.

Dapat dikatakan bahwa belajar bahasa Arab merupakan usaha untuk membentuk kebiasaan baru secara dasar, artinya dalam proses

${ }^{4}$ Muhbib Abdul Wahab, Pemikiran Tammam Hassan Dalam Pembelajaran Bahasa Arab, (Jakarta: UIN Jakarta Press, 2009) hal. 2.

Jurnal Ilmiah Al QALAM, Vol. 10, No. 19, Januari-Juni 2017 
Hasan: Keterampilan Mengajar Bahasa Arab Materi Istima Menggunakan Media Lagu

belajar bahasa arab ada kurikulum dan tujuan yang hendak dicapai sehingga tercapai suatu kebiasaan baru yaitu kemampuan berbahasa Arab.

Kemampuan bahasa Arab aktif yaitu kemampuan berkomunikasi, baik secara lisan maupun tulisan, seperti membuat karangan. Sedangkan kemampuan bahasa Arab pasif adalah kemampuan untuk memahami pembicaraan orang lain dan kemampuan memahami bacaan. Kemampuan berbahasa arab secara positif terhadap bahasa Arab tersebut sangat penting, karena dapat membantu memahami sumber ajaran agama Islam yaitu Al-Qur'an dan Al-Hadits, kitab-kitab bahasa Arab yang berkenaan dengan ajaran agama Islam.

Mempelajari bahasa Arab sebagai bahasa asing, tidak lepas dari prinsip-prinsip linguistik, yang menyatakan bahwa bahasa adalah bahasa ucapan, karena itu sebelum peserta didik belajar membaca dan menulis terlebih dahulu belajar mendengarkan ${ }^{5}$.

Adapun aspek-aspek kemampuan/kemahiran berbahasa Arab dapat ditunjukkan dengan adanya kemampuan menyimak (استماع), kemampuan membaca (قراءة), kemampuan menulis (كتابة). Bahkan ada yang menambahkan keterampilan dalam bahasa Arab dengan kemahiran budaya Arab sebagai kemahiran kelima dalam bahasa Arab. ${ }^{6}$ Aspek-aspek tersebut pada dasarnya dapat digolongkan menjadi dua bagian yaitu; Kemampuan Reseptif (menerima), dan kemampuan ekspresif (mengeluarkan) ${ }^{7}$.

\footnotetext{
${ }^{5}$ Muljanto Sumardi, Pedoman Mempelajari Bahasa Arab pada Perguruan Tinggi Agama Islam, (Jakarta: DEPAG RI, 1975), hal.118.

${ }^{6}$ Ahmad Fuad Effendy, Sejarah Peradaban Islam, (Malang: Misykat, 2014), hal. 4 .

${ }^{7}$ Muljanto Sumardi, Pedoman Mempelajari Bahasa Arab pada Perguruan Tinggi Agama Islam, ...hal.118.
}

Jurnal Ilmiah Al QALAM, Vol. 10, No. 19, Januari-Juni 2017 
Hasan: Keterampilan Mengajar Bahasa Arab Materi Istima Menggunakan Media Lagu

Kemampuan reseptif meliputi, menyimak, artinya seseorang dikatakan mahir berbahasa Arab yaitu apabila dia mampu memahami segala ucapan orang lain yang berbahasa Arab, baik disengaja ataupun tidak disengaja. Sedangkan kemampuan ekspresif, meliputi tiga aspek, yaitu; Kemampuan membaca, kemampuan berbicara, dan kemampuan menulis. Dari tiga ini termasuk diantara tanda-tanda seseorang memiliki kemampuan berbahasa arab.

Kemampuan berbahasa Arab merupakan kecakapan yang harus dimiliki sebagai dasar dalam penggunaan bahasa itu sendiri, baik itu secara aktif maupun pasif. Dalam praktek berbahasa ada kegiatankegiatan mendengarkan, berbicara, mendengar membaca dan menulis ${ }^{8}$.

Menurut Henry Guntur Tarigan, kemampuan atau kemahiran berbahasa mempunyai empat komponen, yaitu : ketrampilan menyimak, ketrampilan berbicara, ketrampilan membaca, ketrampilan menulis ${ }^{9}$.

Kegiatan-kegiatan dalam berbahasa yang tersebut diatas merupakan aturan-aturan umum, jadi tidak semua bahasa mencakup keempat komponen tersebut. Demikian juga dengan berbahasa Arab, seseorang dapat dikatakan mampu atau mahir berbahasa Arab, apabila dapat terampil dari keempat komponen tersebut.

Berbahasa Arab diajarkan secara intensif dalam pengajaran bahasa arab di sekolah ataupun di madrasah. Sebagai tujuan pengajaran bahasa pada umumnya dan pengajaran bahasa Arab pada khususnya. Kemampuan berbahasa Arab dalam pelajaran bahasa Arab yang diberikan di madrasah adalah sebagai penunjang dalam memahami dan

${ }^{8}$ A. Akrom Malibary, Pengajaran Bahasa Arab Di Madrasah Aliyah, (Jakarta: Bulan Bintang, 1987), hal.2.

${ }^{9}$ Henry Guntur Tarigan, Strategi Pengajaran dan Pembelajaran Bahasa, (Bandung: Angkasa, 1990), hal. 191.

Jurnal Ilmiah Al QALAM, Vol. 10, No. 19, Januari-Juni 2017 
Hasan: Keterampilan Mengajar Bahasa Arab Materi Istima Menggunakan Media Lagu

mendalami ajaran agama islam, sehingga kemampuan bahasa Arab pada peserta didik madrasah belum mencapai taraf yang sempurna, karena pengajaran bahasa Arab di madrasah bersifat pada pengenalan atau penguasaan tahap awal dan belum sampai pada taraf mempraktekkan bahasa Arab tersebut secara sempurna.

Keterpaduan kedua konsep di atas, yakni konsep belajar dan konsep mengajar, melahirkan konsep baru yang disebut proses belajar mengajar (PBM). Yang mana proses belajar mengajar merupakan rangkaian kegiatan yang dilakukan murid beserta guru dalam kegiatan pengajaran dengan menggunakan sarana dan fasilitas pendidikan yang ada untuk mencapai tujuan yang telah ditetapkan dalam kurikulum.

Dalam proses belajar mengajar peserta didik tidak lagi dipandang sebagai objek melainkan subjek yang aktif untuk berlatih, mencari, mengolah, menemukan dan menggunakan pengetahuan, sikap dan keterampilan agar berlangsung dengan efektif dan efisien.

Mendengar merupakan ketrampilan dalam berbahasa yang suatu kali dikenal atau dimengerti oleh si pengguna bahasa. Tingkatan mendengar secara penuh perhatian dan pemahaman muncul setelah pengguna bahasa mendengarkan hal-hal yang dianggap sepele, yang kemudian dianggap sebagai tingkat menyimak. Oleh karena itu mendengar dan menyimak merupakan suatu urutan dalam ketrampilan berbahasa.

Agar seorang pelajar dapat mendengarkan dengan baik, maka seyogyanya harus menguasai beberapa kemahiran:

1) Mengenal bunyi-bunyi bahasa Arab dan makhrajnya.

2) Membedakan antara huruf-huruf yang berbeda.

3) Memilik kemampuan mengetahui perbedaan antara hurufhuruf yang berbeda.

Jurnal Ilmiah Al QALAM, Vol. 10, No. 19, Januari-Juni 2017 
Hasan: Keterampilan Mengajar Bahasa Arab Materi Istima Menggunakan Media Lagu

4) Mampu dalam tata bahasa Arab dalam menganalisa lambanglambang suara atau kode-kode.

5) Sebaiknya mengetahui arti kosakata bahasa Arab.

6) Mampu memberikan perhatian sepanjang waktu.

7) Adanya dorongan untuk terus menyimak.

8) Berada dalam kondisi jiwa yang penuh toleransi untuk menyimak sehingga ucapan penutur tidak membosankan.

9) Mengetahui perubahan-perubahan yang terjadi dalam makna sebagai akibat dari perubahan bunyi dan tekanan bunyi ${ }^{10}$.

\section{B. Pembahasan}

\section{Pembelajaran Materi Istima' dalam Bahasa Arab di Indonesia}

Secara umum, pembelajaran materi istima' di Indonesia dapat disajikan dalam empat fase sebagai berikut:

a) Fase pengenalan

Pada fase ini dikenalkan bunyi-bunyi huruf arab baik yang tunggal maupun yang sudah disambung dengan huruf-huruf lain dalam kata-kata. Dalam hal ini guru dituntut untuk memberikan contoh pengucapan bunyi dengan baik dan benar, lalu diikuti oleh para pelajar. Akan baik jika menggunakan alat bantu kaset atau gambar-gambar tentang kata-kata yang dimaksud. Ada beberapa aspek bunyi yang sampai pada saat ini terkadang menjadi masalah dalam mempelajari bahasa arab sebagai bahasa asing. Menurut Hasan dan Suwailih dalam Mudzakkarat al-Daurat alTarbawiyyah (1986) di antara aspek-aspek itu adalah:

a. Bunyi harakat pendek dan panjang;

${ }^{10}$ Abdul Wahab Rosyidi dan Mamlu'atul Ni'mah,Memahami Konsep Dasar Bahasa Arab, (Malang: UIN Maliki Press, 2012), hal. 86.

Jurnal Ilmiah Al QALAM, Vol. 10, No. 19, Januari-Juni 2017 
Hasan: Keterampilan Mengajar Bahasa Arab Materi Istima Menggunakan Media Lagu

b. Bunyi huruf-huruf yang sepintas mirip;

c. Bunyi huruf-huruf ber-tasydid;

d. Bunyi alif-lam syamsiyah dan qamariyyah;

e. Bunyi huruf ber-tanwin;

f. Bunyi huruf-huruf yang di-sukun-kan di akhir kata atau kalimat untuk meringankan ucapan.

b) Fase pemahaman permulaan

Pada fase ini para pelajar diajak untuk memahami pembicaraan sederhana yang dilontarkan oleh guru tanpa respon lisan, tetapi dengan perbuatan. Sebagai tahap permulaan, merespon dengan perbuatan dipandang lebih ringan dibandingkan dengan lisan.

Bentuk respon perbuatan ini dapat berupa:

1. Melakukan perintah secara fisik.

2. Bereaksi pada seruan.

3. Menjawab pertanyaan secara tertulis atau melakukan perintah dengan tulisan atau menggambar di atas kertas.

4. Melakukan perintah dengan menggunakan gambar, sketsa, denah dan sebagainya, yang sudah disediakan oleh guru. Dalam hal ini guru membagikan kertas yang didalamnya ada gambar atau sketsa, atau denah. Para pelajar dalam hal ini mendengarkan perintah guru, lalu mengerjakan apa yang diperintahkannya dengan mengisi tempat kosong dalam gambar atau sketsa atau denah itu. Materi yang diberikan dapat berupa bacaan yang dibacakan oleh guru, atau cerita dalam rekaman kaset.

Jurnal Ilmiah Al QALAM, Vol. 10, No. 19, Januari-Juni 2017 
Hasan: Keterampilan Mengajar Bahasa Arab Materi Istima Menggunakan Media Lagu

c) Fase pemahaman pertengahan

Pada fase ini pelajar diberi pertanyaan-pertanyaan secara lisan atau tertulis. Semantara itu kegiatan-kegiatan yang bisa dilakukan pada fase ini adalah:

1) Guru membacakan bacaan pendek atau memutar rekaman.

Setelah itu guru memberikan pertanyaan-pertanyaan mengenai isi bacaan/rekaman tersebut. Jawaban pelajar bisa berbentuk lisan atau tulisan.

2) Guru memutar rekaman percakapan dua orang penutur asli (al-nathiq al-ashli). Selanjutnya guru menanyakan isi rekaman itu. Pertanyaan yang diajukan dalam poin ini lebih mendetail dibandingkan dengan poin diatas.

3) Guru memutar rekaman percakapan seseorang, mislanya dalam telepon. Dalam percakapan ini yang terdengar hanya satu orang, sedangkan kata-kata lawan bicaranya tidak terdengar. Para pelajar mendengarkan percakapan ini dengan seksama, lalu mereka diminta untuk menebak apa yang dikatakan oleh lawn bicara orang itu.

d) Fase pemahaman lanjutan

Pada fase ini para pelajar diberi latihan untuk mendengarkan berita-berita dari radio atau TV. Bisa juga mendengarkan komentar-komentar tentang hal ihwal tertentu yang disiarkan oleh radio atau TV. Selain itu bisa juga dalam bentuk menyimak rekaman tentang kegiatan tertentu yang bisa disajikan di laboratorium. Dalam kegiatan ini para pelajar dianjurkan untuk mendengarkan sambil membuat catatan mengenal fakta-fakta tertentu yang terjadi selama kegiatan yang terekam dalam kaset seperti nama, tanggal, tahun, tempat, waktu, Jurnal Ilmiah Al QALAM, Vol. 10, No. 19, Januari-Juni 2017 
Hasan: Keterampilan Mengajar Bahasa Arab Materi Istima Menggunakan Media Lagu

dan sebagainya. Hal ini dilakukan untuk menolong mereka dalam mengingat. Setelah itu mereka ditugaskan untuk membuat ringkasan berbahasa arab yang mereka kuasai tentang inti pembicaraan.

1) Menyimak siaran radio dan TV.

Menyimak siaran radio dan TV merupakan proses menyimak yang sangat tinggi. Karena siarannya tidak dapat diulang kembali, jika bagian pertama dari siaran tersebut terlewat maka akan sulit merangkai dengan bagian selanjutnya.

2) Menyimak rekaman tentang kegiatan tertentu.

Kegiatan menyimak dari rekaman tentang kegiatan tertentu merupakan kegiatan yang proses menyimak tidak serumit dari menyimak siaran radio dan TV karena rekaman dapat diputar kembali.

\section{Tujuan Pembelajaran Istima'}

Diantara tujuan pembelajaran istima' menurut Akhmad Fuad Ulyan:

1) Mampu menyimak, perhatian, dan terfokus pada materi yang didengar;

2) Mampu mengikuti apa yang didengar dan menguasainya sesuai dengan tujuan menyimak;

3) Mampu memahami apa yang didengar dari ucapan penutur dengan cepat dan tepat;

4) Menanamkan kebiasaan mendengar sesuai dengan nilai sosial dan pendidikan yang sangat penting;

5) Menanamkan segi keindahan pada saat menyimak;

Jurnal Ilmiah Al QALAM, Vol. 10, No. 19, Januari-Juni 2017 
Hasan: Keterampilan Mengajar Bahasa Arab Materi Istima Menggunakan Media Lagu

6) Mampu mengetahui kosakata sesuai dengan bentuk perkataan yang didengar;

7) Mampu mengetahui makna kosakata sesuai dengan bentuk perkataan yang didengar;

8) Mampu menetapkan kebijaksanaan atas perkataan yang didengar dan menetapkan keputusan yang sesuai ${ }^{11}$.

\section{Macam-macam Pembelajaran Istima'}

Ada beberapa jenis pembelajaran istima':

1) Menyimak secara terfokus, yaitu menyimak dengan penuh kesengajaan yang dilakukan seorang dalam kehidupannya dalam belajar dan bermasyarakat, misalnya menyimak pidato, khutbah, dll.

2) Menyimak tidak terfokus, yaitu menyimak apa yang tersebar di sekitar kita, misalnya menyimak radio dan televisi bersama beberapa teman.

3) Menyimak secara bergantian, yaitu sekelompok orang yang sedang diskusi dengan judul tertentu, di sini orang berbicara sedang yang lain mendengarkan.

4) Menyimak dengan menganalisa, yaitu menganalisa apa yang telah didengar oleh penutur. ${ }^{12}$

\section{Beberapa Masalah dalam Aktivitas Istima'}

1) Kesulitan peserta didik dalam menangkap suara tertentu dari bahasa yang dipelajari.

${ }^{11}$ Abdul Wahab Rosyidi dan Mamlu'atul Ni'mah, Memahami Konsep Dasar Bahasa Arab, (Malang: UIN Maliki Press, 2012), hal. 85.

${ }^{12}$ Abdul Wahab Rosyidi dan Mamlu'atul Ni'mah, Memahami Konsep Dasar Bahasa Arab, (Malang: UIN Maliki Press, 2012), hal. 87.

Jurnal Ilmiah Al QALAM, Vol. 10, No. 19, Januari-Juni 2017 
Hasan: Keterampilan Mengajar Bahasa Arab Materi Istima Menggunakan Media Lagu

2) Kesulitan dalam keharusan memahami, menangkap setiap kata. Jika ada sesuatu yang terlewatkan, peserta didik merasa gagal dan khawatir.

3) Peserta didik memahami pembicaraan seseorang dengan cara pelan.

4) Butuh mendengar lebih dari satu kali.

5) Keterbatasan kemampuan peserta didik dalam mengambil seluruh informasi.

6) Jika kegiatan istima' terlalu lama, peserta didik semakin merasa sulit untuk berkonsentrasi. ${ }^{13}$

\section{Pembelajaran Bahasa Arab Materi Istima' dengan Media}

\section{Lagu}

Pembelajaran mengandung arti dari proses yang berhubungan dengan belajar. Gagne dan Brings, menyebutkan pembelajaran sebagai "Instructional is a set of even which effects learners is such a way that learning is facilitated". 14 Definisi ini menyatakan bahwa pengetahuan manusia tentang sesuatu merupakan implikasi dari pemberian informasi kepadanya.

Dengan menggunakan media musik dan lagu diharapkan ketika pembelajaran sedang berlangsung akan tercipta suasana yang kondusif, rasa bosan yang dialami peserta didik berangsur-angsur hilang terlebih lagi musik dan lagu yang digunakan sudah familiar dan tidak asing lagi di kalangan peserta didik.

Pemutaran media musik dan lagu dapat melalui media compact disk (CD) dan player yang telah dimasukan beberapa jenis

${ }^{13}$ Abdul Wahab Rosyidi dan Mamlu'atul Ni'mah, Memahami Konsep Dasar Bahasa Arab, (Malang: UIN Maliki Press, 2012), hal. 88.

${ }^{14}$ M. Ali, Guru dan Proses Belajar Mengajar, (Bandung: Sinar Baru, 2008), cet. Ke-5, hal. 13 .

Jurnal Ilmiah Al QALAM, Vol. 10, No. 19, Januari-Juni 2017 
Hasan: Keterampilan Mengajar Bahasa Arab Materi Istima Menggunakan Media Lagu

musik dan lagu dalamnya. Selain itu juga dewasa ini alat elektronik semakin canggih, HP sekalipun dapat dijadikan sebuah media ketika pembelajaran berlangsung.

Penggunaan media musik dan lagu juga dapat dikombinasikan dengan menggunakan jenis permainan bahasa. Di antara permainan bahasa yang dapat diaplikasikan adalah bisik berantai (al asror al mutastalstil), perintah bersyarat, siapa yang berbicara (man al mutahadist), bagaimana saya pergi (kaifa azhhab).

Adapun langkah-langkah yang dapat dilakukan guru dalam memanfaatkan media musik dalam proses pembelajaran istima' adalah sebagai berikut:

a. Harus menjelaskan kepada siswa. Dengan pendek kata, guru diharapkan bisa meminimalisir kesulitan siswa dalam memahami teks istima' dalam sebuah lagu dengan cara yang mudah diterima.

b. Siswa mendiskusikan lirik lagu yang telah dibacakan dan diakhiri dengan menyampaikan pertanyaan-pertanyaan yang berkaitan dengan tujuan yang dimaksud.

c. Menyuruh siswa untuk membuat ringkasan lirik lagu yang telah didengar dan menyampaikan ringkasan tersebut secara lisan di hadapan teman-teman di kelas.

d. Mengevaluasi pencapaian siswa dengan cara mengajukan beberapa pertanyaan secara mendalam serta dekat dengan tujuan yang hendak dicapai sehingga bisa dipakai untuk mengukur tingkat kemajuan siswa. ${ }^{15}$

${ }^{15}$ Bisri Mustofa dan M. Abdul Hamid, Metode dan Strategi Pembelajaran Bahasa Arab, (Malang: UIN Maliki Press,2012), h. 83-84. dengan beberapa perubahan.

Jurnal Ilmiah Al QALAM, Vol. 10, No. 19, Januari-Juni 2017 
Hasan: Keterampilan Mengajar Bahasa Arab Materi Istima Menggunakan Media Lagu

Manfaat penggunaan musik untuk membantu proses pembelajaran yaitu :

1) Musik akan membuat peserta didik rileks dan mengurangi stress yang akan menghabat pembelajaran;

2) Merangsang kreativitas dan kemampuan berpikir peserta didik sehingga dapat memporoleh hasil yang lebih baik;

3) Membantu kreativitas dengan membawa otak pada gelombang tertentu;

4) Merangsang minat baca, keterampialn motorik dan perbendaharaan kata;

5) Sangat efektif untuk proses pembelajaran yang melibatkan pikir sadar maupun pikiran bawah sadar.

Untuk menciptakan suasana yang medukung proses belajar, otak perlu mendapat rangsangan yang sesuai, sehingga otak dapat dengan mudah menyerap informasi dan mengerti informasi dan mengembangkan keterampilan berpikir.

Manfaat musik sebenarnya tergantung pada cara kita menggunakannya, kapan dan apa saja jenis musiknya. Berikut penggunaan musik dalam proses pembelajaran.

1. Musik digunakan sebagai pembukaan sehingga pada waktu yang sesuai akan sangat membantu mempengaruhi perhatian peserta didik di awal proses pembelajara.

2. Musik digunakan sebagai pembatas waktu, contonya ketika guru memberikan tugas kepada peserta didik, maka guru dapat membatasi waktu untuk mengerjakan tugas sampai selesai musik tersebut.

Jurnal Ilmiah Al QALAM, Vol. 10, No. 19, Januari-Juni 2017 
Hasan: Keterampilan Mengajar Bahasa Arab Materi Istima Menggunakan Media Lagu

3. Musik digunakan untuk membantu diskusi, saat melakukan diskusi mainkan musik sebagai latar belakang. Pesan musik disini adalah untuk menciptakan atmosfir yang mendukung proses diskusi.

4. Musik digunakan untuk membangkitkan semangat dan energi, saat suasana kelas sedang menurun, peserta didik sudah mulai mengantuk, bosan, atau letih mainkan musik dengan tempo yang tinggi sambil melakukan gerak badan atau brain gym.

5. Musik untuk penutup, jika musik ada sebagai pembuka maka harus ada musik sebagai penutup. Musik ini dimainkan setelah peserta didik selesai belajar dan bersikap untuk pulang sehinnga pada saat pulang peserta didik dapat pulang senang dan gembira.

Perbedaan belajar dengan menggunakan musik dengan belajar tanpa musik :

\begin{tabular}{|l|l|}
\hline \multicolumn{1}{|c|}{ Tanpa musik } & \multicolumn{1}{|c|}{ Mengunakan musik } \\
\hline $\begin{array}{l}\text { Denyut nadi dan tekanan darah } \\
\text { meningkat sehingga otak menjadi } \\
\text { tegang sulit untuk menerima } \\
\text { materi pelajaran }\end{array}$ & $\begin{array}{l}\text { Deyut nadi dan tekanan darah } \\
\text { rendah sehingga otak menjadi } \\
\text { relaks dan mudah untuk } \\
\text { menerima materi pelajaran. }\end{array}$ \\
\hline $\begin{array}{l}\text { Gelombang otak semakin cepat } \\
\text { sehingga akan mengakibatkan } \\
\text { pesan yang sudah disampaikan ke } \\
\text { otak akan cepat hilang dan tidak } \\
\text { tersimpan ke longthrem memory. }\end{array}$ & $\begin{array}{l}\text { delombang otak melambat } \\
\text { sehinga peserta didik akan } \\
\text { longthrem memory. }\end{array}$ \\
\hline $\begin{array}{l}\text { Otot-otot menegang, sulit untuk } \\
\text { menerima materi pembelajaran. }\end{array}$ & $\begin{array}{l}\text { Otot-otot relaks, mudah untuk } \\
\text { menerima materi pelajaran. }\end{array}$ \\
\hline
\end{tabular}

Jurnal Ilmiah Al QALAM, Vol. 10, No. 19, Januari-Juni 2017 
Hasan: Keterampilan Mengajar Bahasa Arab Materi Istima Menggunakan Media Lagu

Salah satu jenis media yang dapat dipergunakan adalah musik/lagu. Penggunaan media ini tentunya sangat mengutamakan keaktifan, kreatifitas, serta inovasi dari guru bersangkutan. Karena tanpa adanya hal tersebut dapat dipastikan media musik/lagu tidak akan berjalan dengan semestinya dan hasilnya pun mungkin tidak memberikan nilai positif bagi pembelajaran.

Dewasa ini, para peneliti metode pembelajaran bahasa Arab berkreasi dalam menciptakan metode pengajaran bahasa Arab. Salah satunya adalah dengan menggunakan teori Multiple Intelligence dalam pembelajaran bahasa Arab. ${ }^{16}$ Metode Multiple Inteligence adalah teori kecerdasan yang ditemukan oleh Howard Gardner (menggeser paradigma kecerdasan IQ yang hanya bisa diukur dengan hanya mengandalkan serangkaian test yang dilakukan. Kecerdasan Multiple Inteligence berisikan kecerdasan spasial, kecerdasan linguistik, kecerdasan interpersonal, kecerdasan musikal, kecerdasan naturalis, kecerdasan kinestetik/badani, kecerdasan intrapersonal, kecerdasan logis-matematis atau yang lebih sering dikenal dengan SLIM N BIL.

Lebih lanjut Zainal Arifin Ahmad menjelaskan kecerdasan musik dapat disinergikan dengan pembelajaran bahasa Arab. Adapun contoh dari metode pembelajaran kecerdasan musikal ini antara lain melalui diskografi (penggunaan musik untuk mengilustrasikan, mewujudkan, atau menjelaskan materi), kegiatan bernyanyi, maupun melalui menggunakan musik suasana (penggunaan musik yang

\footnotetext{
${ }^{16}$ Zainal Arifin Ahmad, Pengembangan Model Pembelajaran Bahasa Arab Berbasis Teori Multiple Intelligence Jurnal Al Mahara Vol 1, N0 1, Desember 2015, hal. 6-8.
}

Jurnal Ilmiah Al QALAM, Vol. 10, No. 19, Januari-Juni 2017 
Hasan: Keterampilan Mengajar Bahasa Arab Materi Istima Menggunakan Media Lagu

membangun suasana yang cocok untuk pembelajaran bahasa Arab) serta nyanyian Arab atau lagu popular di kalangan siswa yang telah dialihbahasakan menjadi bahasa Arab. Melalui musik dan lagu, kecerdasan musikal siswa dapat dikembangkan. Melalui musik dan lagu itu pula, materi pelajaran menjadi lebih menarik dan akan mudah diingat. Oleh karena itu, pemanfaatan musik dan lagu sebagai metode pembelajaran bahasa Arab menjadi sangat penting artinya bagi peningkatan efektifitas proses pembelajaran bahasa Arab. ${ }^{17}$

Di sekolah TK atau MI, porsi penggunaan masih besar (walaupun di MI semakin berkurang porsinya) banyak sekali musik yang sering diajarkan dengan lirik yang sederhana. Lirik sederhana tersebut diganti dengan kalimat dalam bahasa Arab yang sederhana juga dan sesuai dengan logika mereka. Berikut ini lirik yang digunakan dalam pembelajaran bahasa Arab. Tapi tidak menutup kemungkinan tingkat pendidikan yang lebih tinggi lain seperti Madrasah Tsanawiyah maupun Madrasah Aliyah bahkan perguruan tinggi sekalipun.

Contoh pertama musik yang sering didengar peserta didik TK/MI seperti lagu Dua Mata Saya, kemudian diubah menjadi lirik dalam bahasa Arab seperti berikut ini (Lebih baik lagi diiringi dengan instrumen musik yang sesuai).

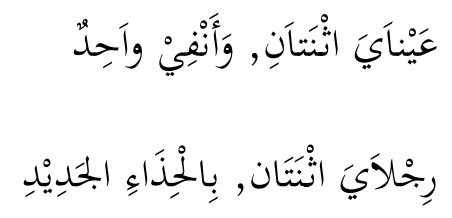

${ }^{17}$ Zainal Arifin Ahmad, Pengembangan Model Pembelajaran Bahasa Arab Berbasis Teori Multiple Intelligence..., h. 15.

Jurnal Ilmiah Al QALAM, Vol. 10, No. 19, Januari-Juni 2017 
Hasan: Keterampilan Mengajar Bahasa Arab Materi Istima Menggunakan Media Lagu

$$
\begin{aligned}
& \text { يَدَايَ اثْنَتَانِ, يُمنْنَ وَ يُسْرَى } \\
& \text { وَفَمِيْ وَاحِدُّ, أَقْرَاءْ بِهِ الْقُرْاءَن }
\end{aligned}
$$

Lirik diatas adalah diambil dari lagu anak-anak berjudul Dua Mata Saya

Dua mata Saya, Hidung saya Satu

Dua kaki saya, pakai sepatu baru

Dua tangan saya, yang kiri dan kanan

Satu mulut saya tidak berhenti membaca Quran

Contoh lagu yang kedua yang sering dinyanyikan anak-anak adalah lagu tentang Pelangi yang diubah menjadi lafal bahasa Arab yaitu:

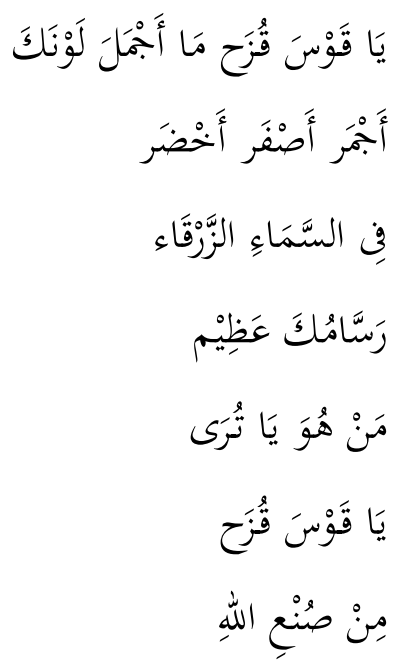

Jurnal Ilmiah Al QALAM, Vol. 10, No. 19, Januari-Juni 2017 
Hasan: Keterampilan Mengajar Bahasa Arab Materi Istima Menggunakan Media Lagu

\section{Versi Indonesia}

Pelangi pelangi alangkah indahmu

Merah kuning hijau

Di langit yang biru

Pelukismu agung

Siapa gerangan?

Pelangi-pelangi ciptaan Tuhan.

\section{PENUTUP}

Materi istima' merupakan salah satu materi dalam pembelajaran bahasa Arab yang sangat kurang disentuh dari pada materi qiraah, qawaid dan kitabah. Hal demikian terjadi karena kurangnya variasi dalam pembelajarannya dan hanya terfokus kepada indera pendengaran saja yakni telinga. Salah satu media yang dapat dilakukan guru untuk membangkitkan kembali motivasi peserta didik adalah dengan bantuan media lagu. Ketika media lagu sudah ada selanjutnya memerlukan kreatifitas dan inovasi dari seorang guru dalam menggunakannya. Di tangan guru yang kreatif dan inovatif materi istima tidak akan menjadi materi yang menakutkan.

Jurnal Ilmiah Al QALAM, Vol. 10, No. 19, Januari-Juni 2017 
Hasan: Keterampilan Mengajar Bahasa Arab Materi Istima Menggunakan Media Lagu

\section{Daftar Pustaka}

Ahmad, Zainal Arifin, Pengembangan Model Pembelajaran Bahasa Arab Berbasis Teori Multiple Intelligence Jurnal Al Mahara Vol 1, N0 1, Desember 2015

Ali, M. Guru dan Proses Belajar Mengajar, Bandung: Sinar Baru, 2008

Effendy, Ahmad Fuad Sejarah Peradaban Islam, Misykat, Malang 2014

Hermawan, Acep, Metodologi Pembelajaran Bahasa Arab, Bandung: PT.Remaja Rosdakarya, 2011.

Malibary, A. Akrom, Pengajaran Bahasa Arab Di Madrasah Aliyah, Bulan Bintang, Jakarta, 1987

Muljanto Sumardi, Pedoman Mempelajari Bahasa Arab pada Perguruan Tinggi Agama Islam, DEPAG RI, Jakarta, 1975

Muradi, Ahmad, Pembelajaran Menulis Bahasa Arab Dalam Perspektif Komunikatif, Jakarta: Prenada Media Group

Mustofa, Bisri dan M. Abdul Hamid, Metode dan Strategi Pembelajaran Bahasa Arab, (Malang: UIN Maliki Press

Rosyidi, Abdul Wahab dan Mamlu'atul Ni'mah,Memahami Konsep Dasar Bahasa Arab, (Malang: UIN Maliki Press, 2012

Sumardi, Muljanto, Pedoman Mempelajari Bahasa Arab pada Perguruan Tinggi Agama Islam, DEPAG RI, Jakarta, 1975

Tarigan, Henry Guntur, Menyimak Sebagai Suatu Keterampilan Berbahasa, Bandung, Angkasa, 1985.

............., Strategi Pengajaran dan Pembelajaran Bahasa, Angkasa, Bandung, 1990

Wahab, Muhbib Abdul, Pemikiran Tammam Hassan Dalam Pembelajaran Bahasa Arab, Jakarta: UIN Jakarta Press

Jurnal Ilmiah Al QALAM, Vol. 10, No. 19, Januari-Juni 2017 